\title{
Temperate Silvopasture Tree Establishment and Growth as Influenced by Forage Species and Cultural Management Practices
}

\author{
James H. Houx III ${ }^{1}$, Robert L. McGraw ${ }^{2}$, H. E. Gene Garrett ${ }^{3}$, Robert L. Kallenbach ${ }^{4}$, Felix B. Fritschi ${ }^{1} \&$ Michael $^{2}$ \\ A. Gold ${ }^{3}$ \\ ${ }^{1}$ Division of Plant Sciences, 1-31 Ag. Bldg., University of Missouri, Columbia, MO, USA \\ ${ }^{2}$ Retired, Division of Plant Sciences, University of Missouri, Columbia, MO, USA \\ ${ }^{3}$ Center for Agroforestry, 203 ABNR, University of Missouri, Columbia, MO, USA \\ ${ }^{4}$ Division of Plant Sciences, 210 Waters Hall, University of Missouri, Columbia, MO, USA \\ Correspondence: James H. Houx III, Division of Plant Sciences, 1-31 Ag. Bldg., University of Missouri, \\ Columbia, MO, USA. Tel: 1-573-882-3023. E-mail: houxj@missouri.edu
}

$\begin{array}{lc}\text { Received: February 15, } 2012 & \text { Accepted: March 5, } 2012 \quad \text { Online Published: May 22, } 2012 \\ \text { doi:10.5539/jas.v4n7p20 } & \text { URL: http://dx.doi.org/10.5539/jas.v4n7p20 }\end{array}$

This work was funded through the University of Missouri Center for Agroforestry under cooperative agreement 58-6227-5-029 and 58-6227-9-059 with the USDA-ARS. The results presented are the sole responsibility of the principal investigators and/or MU and may not represent policies or positions of the ARS.

\begin{abstract}
Tall fescue (Lolium arundinaceum (Schreb.) Darbysh.) is known to inhibit tree growth. Competition for moisture and nutrients, and possibly allelopathy are suspected. This study examined if tall fescue inhibits tree growth more than two other cool-season forages, if tree growth differences are attributed to forage yield or tall fescue's endophyte, and if irrigation and fertilizer can alleviate forage inhibition of tree growth. Four silvopasture tree species were planted into sods of three cool season forage species and grown four years with and without irrigation and fertilizer. Differences in tree growth did not correspond with forage dry matter yield or tall fescue endophyte status. Black walnut and red oak height and diameter growth and pitch $\mathrm{x}$ loblolly pine diameter growth were greater in Kentucky bluegrass and orchardgrass compared to the forage tall fescues [Ky-31 (E+), Ky-31 (E-), and Max-Q]. Irrigation and/or fertilizer did not alleviate forage competition on two tree species.
\end{abstract}

Keywords: agroforestry, silvopasture, tree establishment, competition, tall fescue, endophyte

\section{Introduction}

Most pasture in the Midwestern USA is dominated by tall fescue (Lolium arundinaceum (Schreb.) Darbysh.) and much of this land is unsuitable for row crop production. Establishing trees to create silvopasture on these lands could provide benefits to landowners without sacrificing forage production (Buergler et al., 2004). However, tall fescue is known to inhibit the growth of some tree species more than other forages (Alley et al., 1999; Todhunter \& Beineke, 1979; Van Sambeek \& Garrett, 2004). Researchers are unsure why tall fescue is so antagonistic towards trees, but competition for moisture and nutrients are suspected (Messenger, 1976; Glenn \& Velker, 1993). However, other factors may be involved. For instance, most tall fescue in pastures is infected with an endophyte [Neothyphodium coenophialum (Morgan-Jones \& Gams) Glenn, Bacon \& Hanlin] that confers numerous competitive benefits to its host - e.g., it enhances physiological responses to drought and heat (Belesky et al., 1987; Bacon, 1993; Elmi \& West, 1995; Richardson et al., 1993; Malinowski et al., 1997; Crush et al., 2004; Mark \& Clay, 1996) and may be implicated in allelopathy (Springer, 1996; Walters \& Gilmore, 1976).

Irrigation and fertilization are management practices that might reduce the effect of these factors on tree growth. However, in the initial years after planting, fertilizers may enhance weed growth and burn tree roots (Braun \& Byrnes, 1982; Beineke, 1994), and contribute to shoot dieback (Mooter et al., 2004). Irrigation can improve growth (Ponder, 1983), but irrigating trees grown with forage competition may reduce soil moisture by fostering a vigorous forage crop that transpires more than non-irrigated forage (Dey et al., 1987). These practices require significant financial inputs and it is uncertain that they will alleviate forage competition and improve tree growth. 
To evaluate these factors, this study assessed the growth of four tree species in Kentucky bluegrass (Poa pratensis L.), orchardgrass (Dactylis glomerata L.), and four tall fescues differing in endophyte status and growth habit. The trees were chosen based on their prospective use in silvopasture in the Midwestern United States and their different tolerance to soil and environmental conditions. Pitch $\mathrm{x}$ loblolly pine (Pinus rigida P. Mill. x P. taeda L.) is tolerant to poor soil moisture and nutrient availability, eastern black walnut (Juglans nigra L.) is drought intolerant, northern red oak (Quercus rubra L.) is tolerant to a wide range of soil moisture conditions, and black locust (Robinia pseudoacacia L.) is relatively tolerant to diverse site conditions and is a $\mathrm{N}$-fixing tree. The objectives of this study were to determine: 1) if tall fescue is more competitive than other common forages in the Midwest (Kentucky bluegrass and orchardgrass), 2) if tree growth correlates with differences in forage dry matter yield, 3 ) if tall fescue endophyte status correlates with differences in tree growth, and 4) if irrigation and/or fertilization can be used to reduce the interference associated with forage competition.

\section{Materials and Methods}

\subsection{Study Site, Experimental Design, and Measurements}

This experiment was conducted at the University of Missouri-Horticulture and Agroforestry Research Center (HARC) located in New Franklin, Missouri ( $\left.39^{\circ} 00^{\prime} \mathrm{N} 92^{\circ} 46^{\prime} \mathrm{W}\right)$. The study area was previously in mixed pasture species and the existing vegetation was treated with glyphosate and conventional tillage to prepare the seedbed. Six forage groundcover treatments [endophyte infected (E+) 'Ky-31' tall fescue, non-infected (E-) Ky-31 tall fescue, $(\mathrm{E}+)$ 'Hounddog 5' turf-type tall fescue, 'Max-Q' novel endophyte (E++) tall fescue, orchardgrass, Kentucky bluegrass] and a vegetation-free bare soil control were each established as four separate plots within each of six replications (Figure 1) in September 2002. Each plot measured $5.2 \times 5.2 \mathrm{~m}$ with a $0.9 \mathrm{~m}$ buffer area between plots. The experiment was arranged as a randomized complete block design with six replications. Each replication consisted of (7) forage/grass treatments $\mathrm{x}$ (4) cultural management treatments $=28$ plots. In November 2003, four tree species were planted (black walnut, red oak, black locust and pitch $\mathrm{x}$ loblolly pine) at the corners of a $2.13 \times 2.13 \mathrm{~m}^{2}$ centered in the middle of each plot. One of four cultural management treatments [irrigation (I+F-), fertilizer $(\mathrm{I}-\mathrm{F}+)$, irrigation and fertilizer $(\mathrm{I}+\mathrm{F}+)$, or neither $(\mathrm{I}-\mathrm{F}-)$ ] were applied to all trees within one of the four plots established to each groundcover treatment in each replication.
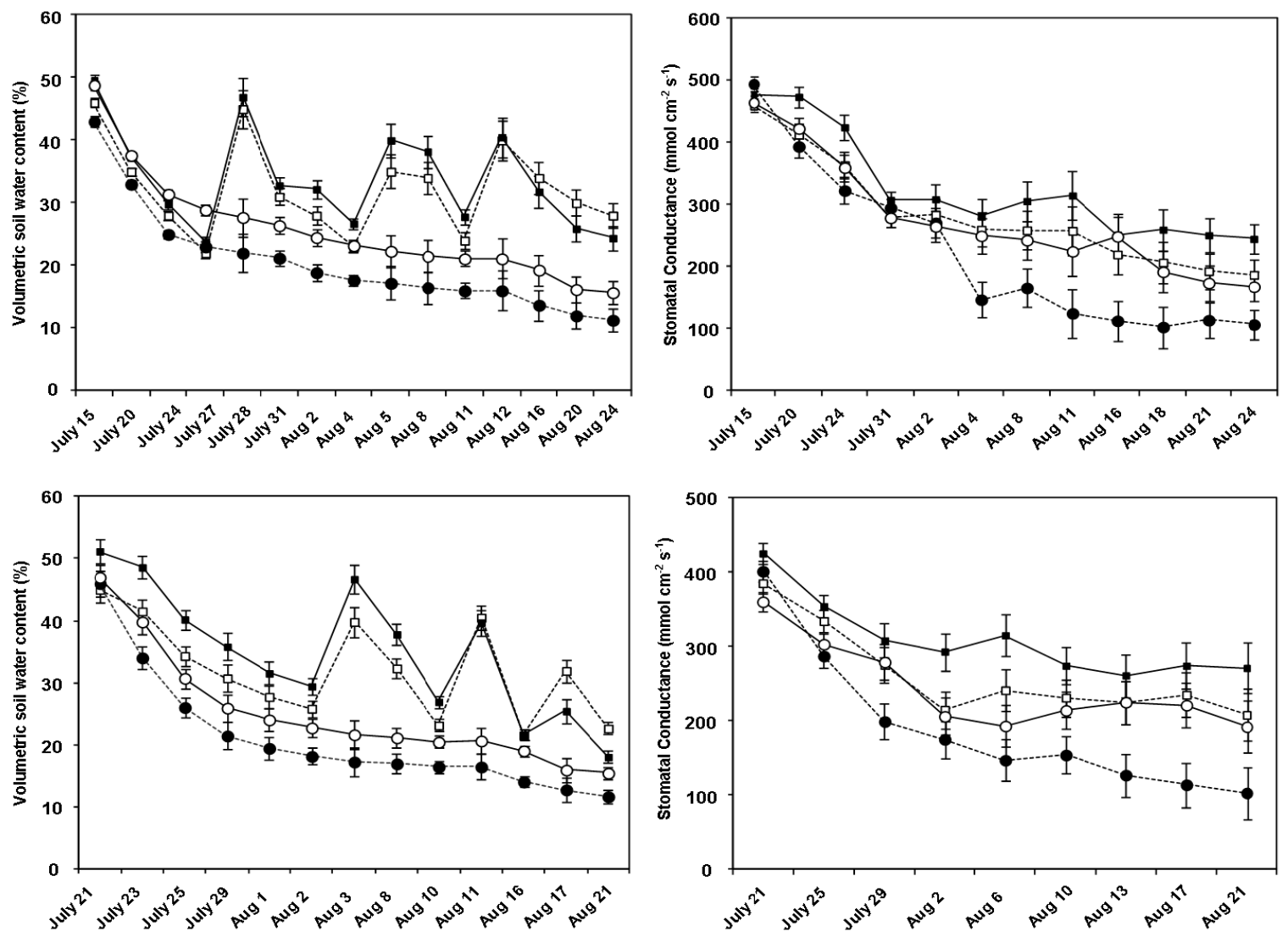

Figure 1. Illustration of one replication displaying groundcover treatment, cultural treatment, and tree location within a plot 
The following seeding rates were used for each groundcover species: tall fescue varieties and orchardgrass $13.5 \mathrm{~kg}$ $\mathrm{ha}^{-1}$, Kentucky bluegrass $7.3 \mathrm{~kg} \mathrm{ha}^{-1}$. Red oak, black walnut, and black locust were planted as 7.6-L containerized trees. Pine was planted as 1-0 bareroot seedlings. Weedmat Tree Squares ${ }^{\circledR}$ (Pak Unlimited, Decatur GA, USA) measuring $0.61 \times 0.61 \mathrm{~m}$ were placed around each tree. This mat size facilitates treatment applications and forage herbage removal, yet is small enough to allow tree and forage roots to intermingle. Drip irrigation was applied with two, 1.9 lph emitters per tree. Fertilizer was applied as Osmocote ${ }^{\circledR}$ slow release 13-13-13 placed beneath weed mat squares at a rate of $55 \mathrm{~g}$ tree ${ }^{-1}$ in March of each year. In late April of each year, an additional $25 \mathrm{~g} \mathrm{~N}, 12.5 \mathrm{~g}$ of $\mathrm{P}$, and $12.5 \mathrm{~g}$ of $\mathrm{K}$ was applied to each tree as $\mathrm{NH}_{4} \mathrm{NO}_{3}$, triple superphosphate, and muriate of potash, respectively.

Neotyphodium immunoassay (Agrinostics Ltd., Watkinsville GA, USA) was conducted to determine the level of tall fescue endophyte infection one year following forage establishment. Ten tillers were randomly selected from two of the four plots seeded to a fescue cultivar within each replication, except Ky-31(E-) tall fescue for which all four plots in each replication were sampled. Infection levels were 82,85 and $83 \%$, respectively for Max-Q, Houndog 5, and Ky-31(E+) tall fescues and 17\% for Ky-31 (E-) tall fescue.

Forage yield was measured in 2005-2007 by cutting, two randomly placed quadrats $(1.0 \times 0.5 \mathrm{~m})$ from each plot to a stubble height of $0.05 \mathrm{~m}$. To avoid the effect of irrigation and/or fertilizer applied to the trees on forage yield, quadrats were not cut within $0.75 \mathrm{~m}$ of any tree. Samples were air dried in a solar drying room $\left(60^{\circ} \mathrm{C}\right.$ max $)$ and weighed. Harvests were conducted when forage height reached approximately $0.35 \mathrm{~m}$. In 2005, growth allowed for harvests on May 15, June 21, August 12, and September 20. In 2006, forages were harvested May 23, June 27, and September 15, and in 2007 on May 10, June 15, and Sept 29. Houndog 5 turf-type tall fescue was harvested only on the first and last date each year. After the quadrats were harvested, the remaining plot area was mowed to a stubble height of $0.05 \mathrm{~m}$ and clipped herbage removed.

Tree height and diameter were measured in November 2003 and in October 2004, 2005, 2006, and 2007. Diameter was measured $0.1 \mathrm{~m}$ above the soil line. Tree growth after planting was assessed as the accumulated four-year height and diameter increment, where:

Four-year growth increment $=$ (height or diameter in 2007 minus height or diameter in November 2003)

Black locust trees in the vegetation-free plots grew rapidly in 2004 and 2005. They were removed from all plots in February 2006 to avoid interference with the growth of the other planted tree species. Therefore, black locust data includes only a two-year increment.

In 2005, Watermark ${ }^{\circledR}$ soil moisture sensors (Irrometer Co., Riverside CA, USA) were installed at $0.15 \mathrm{~m}$ depth in three randomly chosen irrigated plots throughout the experimental site to aid in irrigation timing. In 2006, $\mathrm{ECH}_{2} \mathrm{O}^{\circledR}$ soil moisture sensors (Decagon Devices, Pullman WA) were installed in the root zone $(0.15 \mathrm{~m}$ depth) of irrigated $(\mathrm{I}+\mathrm{F}+)$ and non-irrigated $(\mathrm{I}-\mathrm{F}+)$ black walnut trees in three of the six replications. Soil moisture measurements were taken periodically and irrigation was implemented when $50 \%$ of the irrigated plots had volumetric soil water content between 20 and 23\%. The 2004 growing season was wet and cool, so irrigation was not needed (Table 1). Plots were irrigated six times in 2005 (June 1 and 25; July 11, 20 and 28; Aug 9), three times in 2006 (July 26, Aug 3 and 11), and five times in 2007 (June 15, July 11, Aug 2, 10, and 18). Irrigation was applied for $3.5-4.5 \mathrm{~h}$ during each event. During drought periods in 2006 and 2007 (mid-July - August), measurements were taken periodically to compare volumetric soil moisture content in irrigated plots to those in non-irrigated plots. Also during this time, midday $(1100-1330 \mathrm{hrs})$ stomatal conductance was measured with a SC- $1{ }^{\circledR}$ steady state diffusion porometer (Decagon Devices, Pullman WA, USA) on three of the most recently expanded black walnut leaves in each plot where volumetric soil water content was assessed.

Table 1. Monthly precipitation and average daily high temperature at the Horticulture and Agroforestry Research Center, New Franklin, MO (2004 - 2007)

\begin{tabular}{|c|c|c|c|c|c|c|c|c|c|c|}
\hline \multirow[b]{2}{*}{ Year } & \multicolumn{5}{|c|}{ Precipitation } & \multicolumn{5}{|c|}{ Temperature } \\
\hline & May & June & July & Aug. & Sept. & May & June & July & Aug. & Sept. \\
\hline & ----- & --- & $\mathrm{mm}$ & ----- & ----י & ----- & 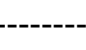 & $-{ }^{\circ} \mathrm{C}-$ & ------ & 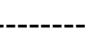 \\
\hline 2004 & 145 & 56 & 134 & 192 & 26 & 24.5 & 26.3 & 28.3 & 26.4 & 26.6 \\
\hline 2005 & 45 & 184 & 19 & 205 & 72 & 24.0 & 29.9 & 32.5 & 31.3 & 27.8 \\
\hline 2006 & 75 & 102 & 97 & 69 & 45 & 24.2 & 29.1 & 32.6 & 32.8 & 24.9 \\
\hline 2007 & 117 & 156 & 48 & 42 & 31 & 26.3 & 28.2 & 29.8 & 33.8 & 28.6 \\
\hline 52-yr avg. & 121 & 106 & 95 & 95 & 99 & 24.5 & 28.9 & 31.6 & 31.0 & 26.8 \\
\hline
\end{tabular}




\subsection{Statistical Analysis}

Prior to analysis of variance, a covariance analysis between beginning height and diameter and final height and diameter for each tree species was conducted using PROC CORR (SAS, Cary NC). Spearman correlation coefficients for each species indicated that growth differences were not confounded by initial seedling size. Further analysis by PROC MIXED indicated there was no significant difference in beginning height or diameter of the trees among any of the groundcover or cultural management treatments. Four-year height and diameter growth increments of black walnut, red oak, and pitch x loblolly pine, and two-year height and diameter growth increments of black locust were subjected to analysis of variance by PROC MIXED with replication and year specified as random. Pair-wise comparisons were conducted using Tukey's Honest Significant Difference (HSD) test $(\mathrm{P}<0.05)$. To meet normality assumptions of the statistical model, square root transformations of height and diameter were conducted. Values presented in tables, figures, and text are non-transformed.

Forage yield from 2005, 2006, and 2007, and cumulative forage yield were subjected to analysis of variance and analyzed by PROC MIXED with replication specified as random. To assess forage yield on tree growth, linear regression analysis was conducted by PROC REG. Regression equations were developed using linear models comparing black walnut, red oak and pitch $x$ loblolly pine height and diameter growth in 2005, 2006, 2007, and cumulatively with each forage species growth during the individual years and cumulatively.

For endophyte effects on tree growth, CONTRAST statements were used in PROC MIXED to compare tree growth in Ky-31 (E-) to that in Ky-31 (E+), compare tree growth in Max-Q (E++) and Ky-31(E-) to that in Houndog $5(\mathrm{E}+)$ and $\mathrm{Ky}-31(\mathrm{E}+)$, and compare tree growth in the forage fescues (Ky-31 (E-), Ky-31 (E+), Max-Q $(\mathrm{E}++))$ to that in Kentucky bluegrass and orchardgrass.

\section{Results and Discussion}

\subsection{Forage Competition}

There were no interactions between forage species and cultural treatment, so data for each are presented separately. During the two years after planting for black locust, and four years after planting for black walnut and red oak, forage competition reduced height and diameter growth compared to growth in vegetation-free plots (Table 2). Growth of pitch x loblolly pine was unaffected by grass treatments. Averaged across all forages, height and diameter growth was reduced 87 and $67 \%$, respectively, for black walnut, 72 and $75 \%$, respectively, for red oak, and 55 and $90 \%$, respectively, for black locust.

Table 2. Black walnut, red oak, and pitch x loblolly pine four-year (2004-2007) height and diameter growth increment and black locust two-year (2004-2005) height and diameter growth increment when grown in seven forage treatments

\begin{tabular}{|c|c|c|c|c|c|c|c|c|}
\hline \multirow[b]{2}{*}{ Treatment } & \multicolumn{4}{|c|}{ Height } & \multicolumn{4}{|c|}{ Diameter } \\
\hline & $\begin{array}{l}\text { Black } \\
\text { walnut }\end{array}$ & $\begin{array}{r}\text { Red } \\
\text { oak }\end{array}$ & $\begin{array}{l}\text { Black } \\
\text { locust }\end{array}$ & $\begin{array}{c}\text { Pitch x } \\
\text { loblolly pine }\end{array}$ & $\begin{array}{l}\text { Black } \\
\text { walnut }\end{array}$ & $\begin{array}{l}\text { Red } \\
\text { oak } \\
\end{array}$ & $\begin{array}{l}\text { Black } \\
\text { locust }\end{array}$ & $\begin{array}{c}\text { Pitch } x \\
\text { loblolly pine }\end{array}$ \\
\hline & \multicolumn{4}{|c|}{ 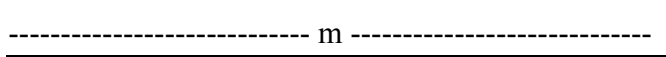 } & \multicolumn{4}{|c|}{ 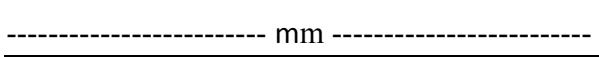 } \\
\hline KY-31 (E-) tall fescue ${ }^{a}$ & $0.155 \mathrm{~d}^{\mathrm{b}}$ & $0.301 \mathrm{~d}$ & $0.689 b c$ & $1.040 \mathrm{a}$ & $5.9 \mathrm{c}$ & $7.7 \mathrm{~cd}$ & $14.5 \mathrm{~b}$ & $32.7 \mathrm{a}$ \\
\hline $\mathrm{KY}-31(\mathrm{E}+)$ tall fescue & $0.150 \mathrm{~d}$ & $0.326 \mathrm{~d}$ & $0.778 \mathrm{~b}$ & $1.284 \mathrm{a}$ & $5.3 \mathrm{c}$ & $7.2 \mathrm{~d}$ & $15.7 \mathrm{~b}$ & $39.7 \mathrm{a}$ \\
\hline Houndog 5 tall fescue & $0.140 \mathrm{~d}$ & $0.389 \mathrm{c}$ & $0.573 \mathrm{c}$ & $1.348 \mathrm{a}$ & $5.7 \mathrm{c}$ & $10.2 \mathrm{c}$ & $13.5 \mathrm{~b}$ & $40.6 \mathrm{a}$ \\
\hline Max-Q tall fescue & $0.165 \mathrm{~cd}$ & $0.394 \mathrm{c}$ & $0.584 \mathrm{c}$ & $1.020 \mathrm{a}$ & $5.7 \mathrm{c}$ & $8.8 \mathrm{~cd}$ & $12.6 \mathrm{~b}$ & $31.2 \mathrm{a}$ \\
\hline Orchardgrass & $0.207 \mathrm{bc}$ & $0.383 \mathrm{c}$ & $0.857 \mathrm{~b}$ & $1.179 \mathrm{a}$ & $8.8 \mathrm{~b}$ & $10.6 \mathrm{c}$ & $16.4 \mathrm{~b}$ & $38.9 \mathrm{a}$ \\
\hline Kentucky bluegrass & $0.254 \mathrm{~b}$ & $0.676 \mathrm{~b}$ & $0.733 \mathrm{~b}$ & $1.245 \mathrm{a}$ & $10.5 \mathrm{~b}$ & $17.1 \mathrm{~b}$ & $14.7 \mathrm{~b}$ & $41.6 \mathrm{a}$ \\
\hline Vegetation-free & $1.416 \mathrm{a}$ & $1.488 \mathrm{a}$ & $1.555 \mathrm{a}$ & $1.272 \mathrm{a}$ & $21.6 \mathrm{a}$ & $41.3 \mathrm{a}$ & $14.6 \mathrm{a}$ & $44.4 \mathrm{a}$ \\
\hline
\end{tabular}


Forage species affected black walnut and red oak height and diameter growth, and black locust height growth (Table 2). In the forages, black walnut generally grew best in association with Kentucky bluegrass and orchardgrass. Height and diameter growth was 66 and $88 \%$ greater, respectively, in Kentucky bluegrass than when averaged across the tall fescues and 35 and 57\% greater, respectively, in orchardgrass than with the fescues. Red oak grew best with Kentucky bluegrass where height and diameter growth was 89 and $92 \%$ greater, respectively, than when averaged across the other forages. Red oak height growth in orchardgrass, Max-Q and Houndog 5 tall fescues was similar and $24 \%$ greater than that in Ky-31 (E+) and (E-) tall fescues. Red oak diameter growth in orchardgrass was $47 \%$ greater than that in $\mathrm{Ky}-31(\mathrm{E}+)$, but similar to that in the other fescues. Black locust growth in Kentucky bluegrass and orchardgrass was always similar to that in Ky-31(E+) and Ky-31 (E-). Height growth was greatest in Kentucky bluegrass, orchardgrass, and $\mathrm{Ky}-31(\mathrm{E}+)$ tall fescue and growth in these forages was 36\% greater than that in Max-Q and Houndog 5 tall fescues, but similar to that in Ky-31 (E-) tall fescue. Black locust diameter growth was similar in all forages.

Kentucky bluegrass was anticipated to be less competitive as its rooting habit is known to be shallower than tall fescues and orchardgrass (Erusha et al., 2002; Ash et al., 1975; Weaver, 1926), and its intolerance to heat forces late-summer dormancy in most years. Tree growth in orchardgrass was often similar to that observed in at least one of the fescue varieties suggesting that the competitive differences between these forage species may be difficult to distinguish. Like tall fescue, orchardgrass tolerates drought, but instead of growing deeper root systems, it relies on its ability to tolerate lower leaf water potentials and extract moisture when soil water content is low (2-15\%) (Volaire \& Lelievre, 2001). This difference in rooting habit may have resulted in less competition for moisture deeper in the soil profile and resulted in greater tree growth, particularly for black walnut, than seen in some of the fescue plots.

Overall, forage competition reduced growth of all trees except pitch x loblolly pine. Similarly, growth reductions associated with grass/forage competition have been reported in beech seedlings (Fagus sylvatica L.) (Coll et al., 2004), grape (Vitis vinifera L.) (Celette et al., 2005), apples (Malus sylvestris L.) (Baugher et al., 1995), peach (Prunus persica L.) (Parker et al., 1993; Tworkoski and Glenn, 2001), pecan (Carya illinoensis (Wangenh.) K. Koch) (Smith et al., 2002), black walnut (Dey et al., 1987) and English walnut (Juglans regia L.) (Picon-Cochard et al., 2001).

Black walnut and red oak height and diameter, and black locust height were always lowest in one of the fescue varieties. However, growth responses to fescue varieties were not consistent among tree species. For instance, black walnut growth was always similar, and the lowest, in the tall fescues. However, red oak growth in Ky-31 $(\mathrm{E}+)$ was always less than that in Houndog 5 while black locust height growth in Max-Q and Houndog 5 was the lowest and less than that in $\mathrm{Ky}-31(\mathrm{E}+)$. These trends suggest that there is a genotype $\mathrm{x}$ genotype interaction between trees and fescues. Further, the growth of the trees appears to follow their tolerance of poor site conditions. For instance, black walnut requires moist, well-drained soil and avoids drought by accessing soil moisture deep in the soil profile (Pallardy \& Rhoads, 1993). With forage competition, aboveground growth was reduced. While leaf area was not directly assessed, this reduced aboveground growth was likely also reflected in reduced leaf area, which in turn likely reduced assimilate production for root growth and thus limited black walnut's ability to reach adequate soil moisture deeper in the soil profile. Red oak grew better than black walnut in forage and this is likely due to its tolerance of a broader range of site conditions (Shreeg et al., 2005). As a nitrogen fixer, black locust grows well under a broad range of site conditions and tolerates unfertile soils (Degomez \& Wagner, 2001), and is the most widely used tree in surface-mine reclamation projects (Ashby et al., 1985). However, forage competition reduced black locust diameter growth by more than $90 \%$ and height growth by more than $50 \%$ so $\mathrm{N}$-fixation alone does not appear to compensate for the reduced growth and provide significant growth benefits to black locust when grown in forages. Pitch $x$ loblolly pine growth was the same in the vegetation-free treatment and all the forage treatments. The absence of a response may be the result of characteristics inherited from the parental species pitch pine and loblolly pine. Pitch pine and loblolly pine are early successional species of droughty, nutrient poor soils of the Piedmont plain (Schultz, 1997) and the pine barren region of New York (Rundel \& Yoder, 2000). Due to their tolerance of poor site conditions, pitch pine and loblolly pine are also used for surface-mine reclamation (Burger \& Zipper, 2002). This inherent ability to compete on poor sites likely contributed to the responses seen here.

\subsection{Forage Yield}

Few differences in tree growth could be attributed to differences in forage yields. When yield was regressed against tree height and diameter growth, low coefficients of determination resulted. Adjusted $\mathrm{R}^{2}$ values ranged from 0.0 to 0.24 for cumulative, annual, or early season forage yield and tree growth models. Responses were inconsistent and variable. A broad range of tree height and diameter growth occurred at any given forage yield 
(data not shown).

In each year and cumulatively, Houndog 5 turf-type tall fescue yielded less than other forages (Table 3). This was not surprising as the cultivar was selected for turf attributes and not forage growth. The only yield differences observed among the remaining forages occurred in 2005 when Ky-31 (E+) tall fescue yielded more than Kentucky bluegrass and orchardgrass, and cumulatively, when Ky-31 (E+) yielded more than orchardgrass. Forage tall fescue, Kentucky bluegrass, and orchardgrass yields were similar to those reported by others (Lauriault et al., 2006; Hill et al., 2002; Durr et al., 2005; Henning \& Risner 1993). Although black walnut, red oak, and black locust often grew less in the highest yielding forages (Ky-31 (E+), Ky-31 (E-), Max-Q tall fescue) they also grew poorly in the lowest yielding one (Houndog 5 tall fescue). When there was no forage yield (vegetation-free plots), black walnut, red oak, and black locust grew well. However, at yields realized in the forage plots, growth was reduced by up to $90 \%$. Certainly, there could be a point where forage stand density, and hence yield, is low enough that competition is reduced and increases in tree growth could be realized. On the other hand, pitch $\mathrm{x}$ loblolly growth was unaffected by forage. Reasons for this are unclear, however, as an evergreen, pitch $\mathrm{x}$ loblolly foliage photosynthesizes before deciduous leaf out in the spring and after deciduous leaf drop in autumn, and at other times during the winter season when temperature and resource capture are not limiting. Further, these times coincide with periods when competition from forage would be minimal compared to the deciduous growing season. This advantage of an extended growing season may partly explain these growth differences.

Table 3. Mean dry matter yield of six grasses in plots with trees at HARC in 2005, 2006, 2007, and cumulative over the study period

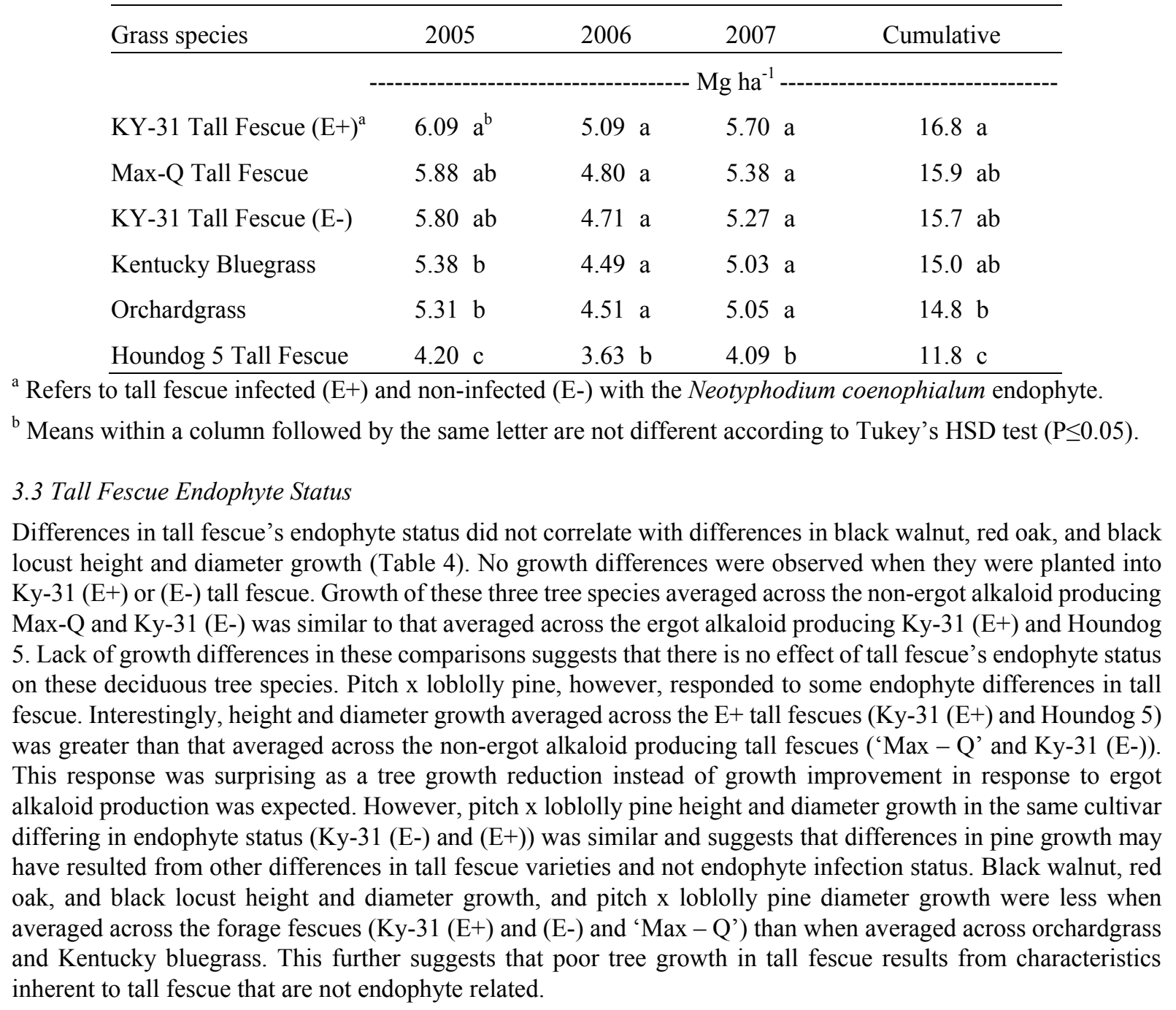


Table 4. Black walnut, red oak, and pitch x loblolly pine four-year (2004-2007) height and diameter growth increment and black locust two-year (2004-2005) height and diameter growth increment when compared in orthogonal contrasts to evaluate grass endophyte status on tree growth

\begin{tabular}{|c|c|c|c|c|c|c|c|c|}
\hline \multirow[b]{2}{*}{ Orthogonal Contrast } & \multicolumn{4}{|c|}{ Height } & \multicolumn{4}{|c|}{ Diameter } \\
\hline & $\begin{array}{c}\text { Black } \\
\text { walnut }\end{array}$ & $\begin{array}{l}\text { Red } \\
\text { oak }\end{array}$ & $\begin{array}{l}\text { Black } \\
\text { locust }\end{array}$ & $\begin{array}{c}\text { Pitch } \mathrm{x} \\
\text { loblolly pine }\end{array}$ & $\begin{array}{c}\text { Black } \\
\text { walnut }\end{array}$ & $\begin{array}{l}\text { Red } \\
\text { oak }\end{array}$ & $\begin{array}{l}\text { Black } \\
\text { locust }\end{array}$ & $\begin{array}{c}\text { Pitch x } \\
\text { loblolly pine }\end{array}$ \\
\hline & ------ & ----- & 10--- & '-----------' & -------- & ---- & m ---- & ---------------- \\
\hline $\mathrm{KY}-31(\mathrm{E}-)^{\mathrm{a}}$ & 0.156 & 0.469 & 0.687 & 1.12 & 5.9 & 9.2 & 14.8 & 33.0 \\
\hline KY $31(\mathrm{E}+)$ & 0.150 & 0.506 & 0.759 & 1.36 & 7.7 & 8.6 & 15.6 & 38.9 \\
\hline significance ${ }^{b}$ & $\mathrm{~ns}$ & ns & ns & $\mathrm{ns}$ & ns & ns & $\mathrm{ns}$ & $\mathrm{ns}$ \\
\hline Max Q and KY-31 (E-) & 0.160 & 0.527 & 0.637 & 1.11 & 6.1 & 9.8 & 13.7 & 32.0 \\
\hline $\begin{array}{l}\mathrm{KY}-31(\mathrm{E}+) \text { and } \\
\text { Houndog } 5\end{array}$ & 0.144 & 0.546 & 0.674 & 1.40 & 5.8 & 10.2 & 14.6 & 39.7 \\
\hline significance & ns & ns & ns & * & ns & ns & ns & * \\
\hline Forage fescues & 0.161 & 0.520 & 0.684 & 1.19 & 5.7 & 9.4 & 14.3 & 34.3 \\
\hline $\begin{array}{l}\text { Orchardgrass and } \\
\text { Kentucky bluegrass }\end{array}$ & 0.226 & 0.750 & 0.792 & 1.31 & 10.1 & 15.5 & 15.5 & 40.4 \\
\hline
\end{tabular}

Kentucky bluegrass

${ }^{a}$ Refers to tall fescue infected (E+) and non-infected (E-) with the Neotyphodium coenophialum endophyte.

$\mathrm{b} *, * *, * * *$ Significant at $0.05,0.01$, and 0.001 probability level, respectively; $\mathrm{ns}=$ non significant $(\mathrm{P} \leq 0.05)$.

\subsection{Irrigation and Fertilizer}

There were few differences in growth when irrigation and/or fertilizer were applied to trees in the forage plots (Table 5). Irrigation plus fertilizer $(\mathrm{I}+\mathrm{F}+$ ) improved black walnut mean diameter growth $45 \%$ relative to applying nothing. Also, fertilizer reduced pitch $\mathrm{x}$ loblolly height and diameter growth compared to applying both fertilizer and irrigation. However, growth was still similar to that where no irrigation or fertilizer was applied. When compared to growth in vegetation-free plots (Table 5), these cultural treatments did not reduce competition and restore growth, suggesting that their use is not warranted. Interestingly, in vegetation-free plots, irrigation and/or fertilizer again had no effect on height or diameter growth.

Table 5. Black walnut, red oak, and pitch x loblolly pine four-year (2004-2007) height and diameter growth and black locust two-year (2004-2005) height and diameter growth when supplied with four cultural treatments and grown in six grasses (With Vegetation) or in vegetation free plots (Vegetation Free)

\begin{tabular}{|c|c|c|c|c|c|c|c|c|}
\hline \multirow[b]{2}{*}{ Treatment } & \multicolumn{4}{|c|}{ Height } & \multicolumn{4}{|c|}{ Diameter } \\
\hline & Black walnut & $\begin{array}{r}\text { Red } \\
\text { oak }\end{array}$ & $\begin{array}{l}\text { Black } \\
\text { locust }\end{array}$ & $\begin{array}{c}\text { Pitch } x \\
\text { loblolly pine }\end{array}$ & Black walnut & $\begin{array}{l}\text { Red } \\
\text { oak }\end{array}$ & $\begin{array}{l}\text { Black } \\
\text { locust }\end{array}$ & $\begin{array}{c}\text { Pitch x loblolly } \\
\text { pine }\end{array}$ \\
\hline \multicolumn{9}{|l|}{ With Vegetation } \\
\hline $\begin{array}{l}\text { No fertilizer or } \\
\text { irrigation }\end{array}$ & $0.164 \mathrm{a}^{\mathrm{a}}$ & $0.386 \mathrm{a}$ & $0.671 \mathrm{a}$ & $1.125 \mathrm{ab}$ & $5.5 \mathrm{~b}$ & $8.8 \mathrm{a}$ & $14.2 \mathrm{a}$ & $36.5 \mathrm{ab}$ \\
\hline Fertilizer & $0.203 \mathrm{a}$ & $0.349 \mathrm{~A}$ & $0.694 \mathrm{a}$ & $1.038 \mathrm{a}$ & $6.9 \mathrm{ab}$ & $9.6 \mathrm{a}$ & $14.6 \mathrm{a}$ & $33.3 \mathrm{~b}$ \\
\hline Irrigation & $0.164 \mathrm{a}$ & $0.441 \mathrm{a}$ & $0.712 \mathrm{a}$ & $1.198 \mathrm{ab}$ & $6.6 \mathrm{ab}$ & $10.8 \mathrm{a}$ & $14.7 \mathrm{a}$ & $40.1 \mathrm{ab}$ \\
\hline Fertilizer plus Irrigation & $0.190 \mathrm{a}$ & $0.435 \mathrm{a}$ & $0.705 \mathrm{a}$ & $1.418 \mathrm{a}$ & $8.0 \mathrm{a}$ & $10.4 \mathrm{a}$ & $14.8 \mathrm{a}$ & $43.0 \mathrm{a}$ \\
\hline \multicolumn{9}{|l|}{ Vegetation Free } \\
\hline $\begin{array}{l}\text { No fertilizer or } \\
\text { irrigation }\end{array}$ & $1.55 \mathrm{a}^{\mathrm{a}}$ & $1.73 \mathrm{a}$ & $1.87 \mathrm{a}$ & $1.71 \mathrm{a}$ & $49.4 \mathrm{a}$ & $43.7 \mathrm{a}$ & $142 \mathrm{a}$ & $55.7 \mathrm{a}$ \\
\hline Fertilizer & $1.43 \mathrm{a}$ & $1.30 \mathrm{a}$ & $1.69 \mathrm{a}$ & $0.99 \mathrm{a}$ & $46.9 \mathrm{a}$ & $35.2 \mathrm{a}$ & $134 \mathrm{a}$ & $42.3 \mathrm{a}$ \\
\hline Irrigation & $1.42 \mathrm{a}$ & $1.24 \mathrm{a}$ & $1.41 \mathrm{a}$ & $1.01 \mathrm{a}$ & $38.6 \mathrm{a}$ & $38.3 \mathrm{a}$ & $157 \mathrm{a}$ & $39.8 \mathrm{a}$ \\
\hline Fertilizer plus Irrigation & $1.60 \mathrm{a}$ & $1.80 \mathrm{a}$ & $1.76 \mathrm{a}$ & $1.38 \mathrm{a}$ & $55.4 \mathrm{a}$ & $49.4 \mathrm{a}$ & $148 \mathrm{a}$ & $39.7 \mathrm{a}$ \\
\hline
\end{tabular}

${ }^{a}$ means within a column followed by the same letter within a vegetation treatment are not different according to Tukey's HSD Test $(\mathrm{P} \leq 0.05)$. 
The reason for a lack of response to these inputs in forage plots is unclear. Forages are known to compete more vigorously than trees for soil moisture and nutrients because of their dense, fibrous root system (Celette et al., 2005; Coll et al., 2006). Because of this rooting architecture, forages likely intercepted much of the fertilizer and irrigation inputs. Forage nearest to irrigated or fertilized trees appeared to grow larger than forages near trees that did not receive these treatments. This suggests that the supplements may have increased nutrient and water uptake by the forages thus, limiting availability of these inputs for the trees as suggested by Cheng and Bledsoe (2004) and may partly explain the lack of tree response. However, during drought events in July and August 2006 and 2007, soil moisture was greater in irrigated plots than in non-irrigated plots, as was black walnut stomatal conductance, suggesting that seedlings benefited from the irrigation (Figure 2).

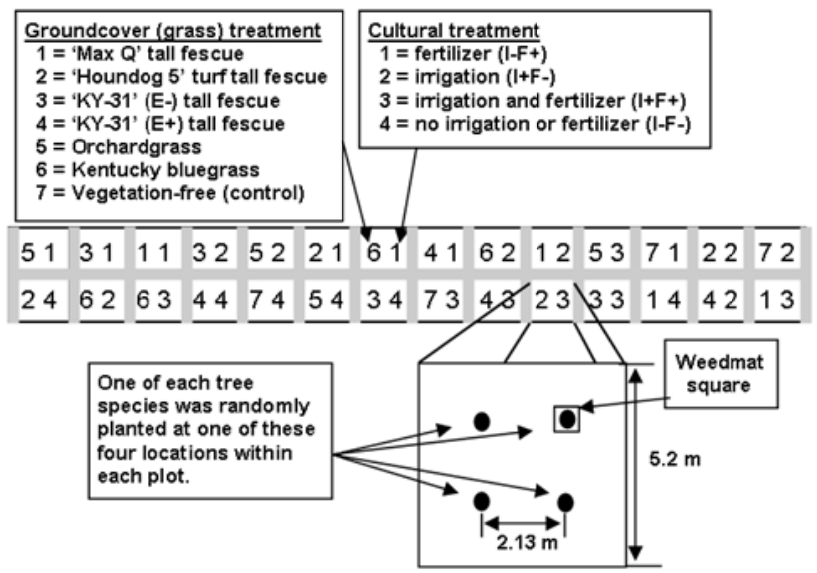

Figure 2. Volumetric soil water content (left) and black walnut stomatal conductance (right) during drought in July and August 2006 (top) and 2007 (bottom) in vegetation-free plots with irrigation (-), vegetation-free plots without irrigation $(\circ)$, grass plots with irrigation $(\square)$ and, grass plots without irrigation $(\bullet)$ (vertical bars represent mean $+/$ std. error)

Higher stomatal conductance should lead to higher photosynthesis and increased growth. Therefore, it is unclear why enhanced growth was not observed in response to irrigation. In vegetation-free plots, black walnut height and diameter growth was greater than when grown with the forages. As expected, soil moisture and stomatal conductance in vegetation-free plots, regardless of whether they were irrigated, were consistently greater than in non-irrigated forage plots. However, stomatal conductance of non-irrigated trees in vegetation-free plots was similar to irrigated trees in forage plots suggesting that seedlings were affected similarly by the respective soil moisture conditions. Since growth differences between trees in forage and vegetation-free plots were large, it appears that factors other than competition for moisture reduced tree growth in forage plots.

Fertilizer was applied at a rate equivalent to $32.2 \mathrm{~g} \mathrm{~N}, 19.7 \mathrm{~g} \mathrm{P}$, and $19.7 \mathrm{~g} \mathrm{~K} \mathrm{~m}^{-2} \mathrm{yr}^{-1}$ and was more than twice that recommended for black walnut when weeds are controlled (Beineke, 1994). Nonetheless, trees did not show signs of over fertilization such as tip dieback. It is therefore assumed that fertilization was not too high for the growing conditions at the site. Some of the lack of response to fertilizer may be attributed to uptake by forages. Forage yield averaged 5.21 Mg ha ${ }^{-1} \mathrm{yr}^{-1}$ in 2005, 2006 and 2007 in areas of the plot not noticeably affected by cultural treatments applied to the trees. At this yield level, forage would remove approximately $5.21-15.6 \mathrm{~g} \mathrm{~N} \mathrm{~m}^{-2} \mathrm{yr}^{-1}$, along with corresponding amounts of $\mathrm{P}$ and $\mathrm{K}$, if forage $\mathrm{N}$ concentration ranged between 1 and $3 \%$. This estimated removal would only be half the amount of $\mathrm{N}$ applied, but, as mentioned earlier, forage nearest fertilized and irrigated trees grew noticeably taller than forage in the rest of the plot where forage yield was assayed so actual nutrient removal may have been greater than the estimated $5.21-15.6 \mathrm{~g} \mathrm{~N} \mathrm{~m}^{-2} \mathrm{yr}^{-1}$.

Often, native fertility is sufficient for young black walnut trees and adding fertilizer can actually reduce growth (Mooter et al., 2004). For these reasons, it has been suggested that fertilizer should not be applied to black walnut in the first few years of growth. However, there is little information elsewhere to suggest that these inputs would not improve growth of the other tree species studied. Although tree growth was not reduced from these inputs, it appears that fertilizer and irrigation are not necessary to improve the growth of these tree species in the initial years after outplanting on good sites when weed control is used.

\section{Conclusion}

Grass competition reduced black walnut, red oak, and black locust growth, but had little effect on pitch x loblolly 
pine. Except for pines, tree growth in tall fescue was often less than that in Kentucky bluegrass or orchardgrass, but responses to forage species were tree species dependent. Tree growth differences were not explained by differences in forage yield or tall fescue's endophyte status suggesting that these factors have little effect on tree growth in pastures. Other properties of tall fescue such as heat and drought tolerance that allow it to maintain growth for a greater part of the year, and differentiate tall fescue from orchardgrass and Kentucky bluegrass, may be responsible. Irrigation and fertilizer neither alleviated the effects of forage competition on black walnut, red oak, or black locust nor improved pitch x loblolly pine growth in forage. Their use to reduce the effects of competition under conditions in this study does not appear warranted. Soil moisture and stomatal conductance measurements indicated that black walnut trees benefited from irrigation, but a lack of growth response between irrigated and non-irrigated trees even under drought conditions suggests that other factors are overriding the benefits of irrigation and reduce tree growth when planted into forage. On good sites such as the one in this study, applying irrigation and fertilizer to trees without forage competition may not be warranted. Pitch $\mathrm{x}$ loblolly pine growth was similar in forage plots and vegetation-free plots and appears to be well suited for silvopasture establishment in tall fescue pastures with minimal weed control inputs. In contrast, red oak, black walnut, and black locust would require vegetation management to maintain adequate growth in the early stages of silvopasture development.

\section{References}

Alley, J. L., Garrett, H. E., McGraw, R. L., Dwyer, J. P., \& Blanche, C. A. (1999). Forage legumes as living mulches for trees in agroforestry practices - preliminary results. Agrofor. Syst., 44, 281-291. http://dx.doi.org/10.1023/A:1006263014054

Ash, A. N., Gross, H. D., \& Noggle, G. R. (1975). Root growth and distribution in Festuca arundinacea. Bull. Torrey Bot. Club., 102(5), 238-243. http://dx.doi.org/10.2307/2484140

Ashby, W. C., Vogel, W. G., \& Rogers, N. F. (1985). Black locust in the reclamation equation. Gen. Tech. Rep., NE-105. USDA-FS, Northeastern For. Exp. Sta., Broomall, PA. p.12.

Bacon, C. W. (1993). Abiotic stress tolerances (moisture, nutrients) and photosynthesis in endophyte-infected tall fescue. Agric. Ecosyst. Environ., 44, 123-141. http://dx.doi.org/10.1016/0167-8809(93)90042-N

Baugher, T. A., Elliot, K. C., \& Glenn, D. M. (1995). Effect of sod competition and root pruning on 'Stayman' apple tree growth and fruit cracking. Hort. Science, 30, 222-226.

Belesky, D. P., Devine, O. J., Pallas Jr, J. E., \& Stringer, W. C. (1987). Photosynthetic activity of tall fescue as influenced by a fungal endophyte. Photosynthetica, 21, 82-87.

Beineke, W. F. (1994). Black walnut plantation management. Purdue University Cooperative Extension Publication FNR-119 Purdue University, West Lafayette, IN.

Braun, J. M., \& Byrnes, W. R. (1982). Growth of black walnut in a fertilized plantation. In Black Walnut for the Future, USDA Forest Service General Technical Report, NC-74. pp. 97-104.

Buergler, A., Fike, J., Burger, J., Mckenna, J., \& Feldhake, C. M. (2004). Forage production and nutritive value within a temperate silvopasture system. in: Book of Abstracts 1st World Congress on Agroforestry 27 June to 2 July. Orlando, Florida, USA.

Burger, J. A., \& Zipper, C. E. (2002). How to restore forests on surface-mined land. Powell River Project--Reclamation guidelines for surface-mined land in southwest Virginia Commonwealth of Virg. Ext. Pub. No. 460-123.

Celette, F., Wery, J., Chantolet, E., Celette, J., \& Gary, C. (2005). Belowground interactions in a vine (Vitis vinifera L.)-tall fescue (Festuca arundinacea Shreb.) intercropping system: Water relations and growth. Plant Soil, 276, 205-217. http://dx.doi.org/10.1007/s11104-005-4415-5

Cheng, X., \& Bledsoe, C. S. (2004). Competition for inorganic and organic N by blue oak (Quercus douglasii) seedlings, an annual grass, and soil microorganisms in a pot study. Soil Biol. Biochem, 36, 135-144. http://dx.doi.org/10.1016/j.soilbio.2003.08.024

Coll, L. P., Balndier, C., \& Picon-Cochard, C. (2004). Morphological and physiological responses of beech (Fagus sylvatica) seedlings to grass-induced belowground competition. Tree Phys., 24, 45-54. http://dx.doi.org/10.1093/treephys/24.1.45 
Crush, J. R., Popay, A. J., \& Waller, J. (2004). Effect of different Neotyphodium endophytes on root distribution of a perennial ryegrass (Lolium perenne L.) cultivar. N.Z. J. Agric. Res., 47, 345-349. http://dx.doi.org/10.1080/00288233.2004.9513603

Degomez, T., \& Wagner, M. R. (2001). Culture and use of black locust. Hort. Tech., 11(2), 279-288.

Dey, D., Conway, M. R., Garrett, H. E., Hinckley, T. S., \& Cox, G. S. (1987). Plant-water relationships and growth of black walnut in a walnut-forage multicropping regime. For. Sci., 33(1), 70-80.

Durr, G. H., Kunelius, H. T., Drapeau, R., McRaie, K. B., \& Fillmore, S. A. E. (2005). Herbage yield and composition of Kentucky bluegrass (Poa pratensis L.) cultivars under two harvest systems. Can. J. Plant Sci., 85, 631-639. http://dx.doi.org/10.4141/P04-121

Elmi, A. A., \& West, C. P. (1995). Endophyte infection effects on stomatal conductance, osmotic adjustment and drought recovery of tall fescue. New Phytol., 131, 61-67. http://dx.doi.org/10.1111/j.1469-8137.1995.tb03055.x

Erusha, K. S., Shearman, R. C., Riordan, T. P., \& Wit, L. A. (2002). Kentucky bluegrass cultivar root and top growth responses when grown in hydroponics. Crop Sci., 42, 848-852. http://dx.doi.org/10.2135/cropsci2002.0848

Glenn, D. M., \& Velker, M. V. (1993). Water transfer diminishes root competition between peach and tall fescue. J. Am. Hort. Soc., 118, 570-574.

Henning, J., \& Risner, N. (1993). Orchardgrass. Univ of Missouri Ext pub G4511. [Online] Available: http: //extension.missouri.edu/explore/agguides /crops/g04511.html. (Jan 30, 2012).

Hill, N. S., Bouton, J. H., Thompson, F. N., Hawkins, L., Hoveland, C. S., \& McCann, M. A. (2002). Performance of tall fescue germplasms bred for high- and low-ergot alkaloids. Crop Sci., 42, 518-523. http://dx.doi.org/10.2135/cropsci2002.0518

Lauriault, L. M., Guldan, S. J., Martin, C. A., \& VanLeeuwen, D. M. (2006). Performance of irrigated tall fescue-legume communities under two grazing frequencies in the southern Rocky Mountains, USA. Crop Sci., 46, 330-336. http://dx.doi.org/10.2135/cropsci2005.0126

Malinowski, D. P., Leuchtmann, A., Schmidt, D., \& Nosberger, J. (1997). Growth and water status in meadow fescue is affected by Neotyphodium and Phialophora species endophytes. Agron. J., 89, 673-678. http://dx.doi.org/10.2134/agronj1997.00021962008900040021x

Mark, S., \& Clay, K. (1996). Physiological responses of Festuca arundinacea to fungal endophyte infection. New Phytol., 133(4), 727-733. http://dx.doi.org/10.1111/j.1469-8137.1996.tb01941.x

Messenger, A. S. (1976). Root competition: grass effects on trees. J. Arboric., 2(12), 228-230.

Mooter, D. P., Harrell, M. O., \& Stepanik, L. J. (2004). Care of newly planted trees. Univ. of Neb. Coop. Ext. Pub. G1195 Lincoln, NE.

Pallardy, S. G., \& Rhoads, J. L. (1993). Morphological adaptations to drought in seedlings of deciduous angiosperms. Can. J. For. Res., 23(9), 339-348. http://dx.doi.org/10.1139/x93-223

Parker, M. L., Hull, J., \& Perry, R. L. (1993). Orchard floor management affects peach rooting. J. Amer. Soc. Hort. Sci., 118(6), 714-718.

Picon-Cochard, C., Nsourou-Obame, A., Collett, C., Guehl, J. M., \& Ferhi. A. (2001). Competition of water between walnut seedlings (Juglans regia) and rye grass (Lolium perenne) assessed by carbon isotope discrimination and delta 18(O) enrichment. Tree Phys., 21(2/3), 183-191. http://dx.doi.org/10.1093/treephys/21.2-3.183

Ponder, F. Jr. (1983). Soil moisture levels and mycrorrhizal infection in black walnut seedlings. Commun. Soil Sci. Plant Anal., 14(6), 507-511. http://dx.doi.org/10.1080/00103628309367384

Richardson, M. D., Hoveland, C. S., \& Bacon, C. W. (1993). Photosynthesis and stomatal conductance of symbiotic and nonsymbiotic tall fescue. Crop Sci., 33, 145-149. http://dx.doi.org/10.2135/cropsci1993.0011183X003300010026x

Rundel, P. W., \& Yoder, B. J. (2000). Ecophysiology of Pines. In Richardson D.M. (ed.) Ecology and Biogeography of Pinus. Cambridge University Press, Cambridge MA. 
Schreeg, L. A., Kobe, R. K., \& Walters, M. B. (2005). Tree seedling growth, survival, and morphology in response to landscape-level variation in soil resource availability in northern Michigan. Can. J. For. Res., 35, 263-273. http://dx.doi.org/10.1139/x04-168

Schultz, R. I. (1997). Loblolly Pine. The ecology and culture of loblolly pine. USDA-FS South. Exp. Sta., New Orleans LA, Agriculture Handbook 713.

Smith, M. W., Cleary, B. S., \& Carroll, B. L. (2002). Fescue sod suppresses young pecan tree growth. Hort. Sci., 37(7), 1045-1048.

Springer, T. L. (1996). Allelopathic effects on germination and seedling growth of clovers by endophyte-free and $\begin{array}{lllll}\text {-infected tall } & \text { Crop }\end{array}$ http://dx.doi.org/10.2135/cropsci1996.0011183X003600060037x

Todhunter, M. N., \& Beineke, W. F. (1979). Effect of fescue on black walnut growth. Tree Planters' Notes, 30(3), 20-23.

Tworkoski, T. J., \& Glenn, D. M. (2001). Yield, shoot and root growth, and physiological responses of mature peach trees to grass competition. Hort. Sci., 36(7), 1217-1218.

Van Sambeek, J. W., \& Garrett, H. E. (2004). Ground cover management in walnut and other hardwood plantings. In Michler C.H. et al. (eds.) Black Walnut in a New Century. Proc $6^{\text {th }}$ Walnut Council res symp. Gen. Tech. Rep. NC-243. USDA-FS, North Central Res. Sta. St. Paul, MN. p.188.

Volaire, F., \& Lelievre, F. (2001). Drought survival in Dactylis glomerata and Festuca arundinacea under similar rooting conditions in tubes. Plant Soil, 229(2), 225-234. http://dx.doi.org/10.1023/A:1004835116453

Walters, D. T., \& Gilmore, A. R. (1976). Allelopathic effects of fescue on the growth of sweetgum. JChem. Ecol., 2(4), 469-479.

Weaver, J. E. (1926). Root development of field crops. First Edition. Mcgraw-Hill New York, NY. p. 297. http://dx.doi.org/10.1007/BF00988812 